\title{
Sovereignty, 'Return to Europe' and Democratic Distrust in the East after 1989 in the Light of Brexit
}

\author{
Michal Kopeček
}

Polexit, Hungexit, Czexit: all appear in current political debates across East Central Europe, though so far only as a political option favoured by a minority. But as we know from Brexit, the situation can change quickly. The parties and movements that like to call themselves 'patriotic' have mobilised the repertoire of anti-Brussels sentiments. We cannot rule out that some countries in the region will follow the British path of exiting the European Union, even though for them this would be even more economically and politically irrational than it is in the British case. However, although these EU-Exiteers occasionally express admiration for the 'proud Albion', they rarely draw parallels between their respective countries and the United Kingdom; their Euroscepticism comes from very different sources. In order to understand the situation in the region today, we need consider its prehistory.

Understanding the reverberations of Brexit in East Central Europe entails rethinking the historical narratives that we have used to make sense of conflicts over sovereignty and democracy in the region since the collapse of communism. For a long time we believed that the main problem for the new democracies was the legacy of communism. A generation later we begin to see that it might well be capitalism, and, more precisely, the 'liberal' meanings attributed to the 'democratic revolutions' of 1989 rather than the ghost of the communist past, that is making trouble. Two of the most formidable enemies of liberal democracy in the region, Viktor Orbán and Jarosław Kaczyński, are not, after all, former communists or their heirs, but former members of the dissident opposition. Thus the past matters, but maybe it matters in a different way than we thought.

The democratic revolutions of 1989 are often portrayed as the victory of human rights politics and civil society's struggle for democratisation. In the first two decades after 1989 the extensive literature on the history of anti-communist dissidence focused on the human rights based democratic opposition and its struggle for democratisation in the international environment after the 1975 Helsinki Accords. Only recently have researchers begun to turn their attention to the 'other side', to explore questions of national identity. Debates about human rights theory appeared far less frequently in samizdat than the numerous and often fierce discussions of national history, its meaning, reinterpretations, national political traditions and their legacies. In other words, collective identities rather than abstract theoretical principles and ideals were at stake. In Poland the motif of 'independence' was of such importance that the chief strategist of the human rights opposition, Jacek Kuron, characterised the opposition with two main epithets: anti-totalitarian and independentist (niepodległościowa).

The discourse of national history proved to be a powerful tool in the hands of the opposition. The most obvious example in this respect was, as the historian of ideas Bronisław Baczko put it, the 'exploding historical memory' of Solidarity in 1980-1. Contemporary history in particular was full of taboos in the official communist historiography, especially with regard to the PolishSoviet relationship (with crucial moments such as the Polish-Soviet war 1919-21, the Ribbentrop-Molotov Pact, the Katyń massacre, the 1944 Warsaw uprising and the 'liberation' of Poland by the Red Army), and as such turned into a moral and political battlefield against the 
regime. The anti-communist opposition in other countries also deployed the power of historical memory in the struggle against state socialist dictatorships. In Hungary, it concerned particularly the revolution of 1956; in Slovakia, the 1944 National Uprising. In a well-known Charter 77 document from 1984 entitled 'The Right for History', Czech dissidents led by Václav Benda questioned official Czechoslovak historiography and the 'politics of amnesia'. Accusing the communist powers of manipulating and corrupting the population's historical memory they called for a renewal of 'authentic national historical memory'. This concept of the 'memory of the nation' would go on to make a dizzying political and commercial career from the late 1990s. It is symptomatic that Benda, who died in 1999, became the patron saint of the Czech 'national memory institute', the Institute for the Study of Totalitarian Regimes established in 2007.

On the ground, the 1989 revolutions were experienced not just as the rebirth of democracy but also as the mythological rise of the nation against an unpatriotic or foreign communist power. Thus, independence and national sovereignty, historically conceived, were closely allied with democratic renewal. This new 'spring of nations' did not at first seem to clash with another popular slogan in the streets of Bratislava or Bucharest, namely that of a 'return to Europe'. But soon things turned out to be more complicated. British conservative ideology partly inspired the Euroscepticism that emerged in the region in the early 1990s, with the neoliberal-conservative critique of the EU's post-Maastricht development embodied - then and now - by the maverick Czech economist Václav Klaus. But to understand the more contemporary articulations of Czexit or Polexit, we should look less to the British influence and more to the recent history of the postcommunist transformation itself.

Neoliberalism is seen by many - especially on the left - as the main cause of the contemporary manifestations of Euroscepticism in East Central Europe today. And, indeed, we saw a lot of it after 1989, sometimes with explicit reference to Thatcherism: the dominance of the market at the expense of labour regulations; cuts in long-term public spending; deregulation; large-scale privatisation and the creation of a new social layer of 'responsible owners'; the replacement of the concept of public welfare as the main principle of social cohesion with the doctrine of 'individual responsibility'. All these ideas gained legitimacy by borrowing from the British and Western history of neoliberalism. Yet it would be a gross oversimplification to say that Orbán in Hungary or the Law and Justice (Prawo $i$ Sprawiedliwość; Pis) regime in Poland are the results of neoliberalism or its discontents alone.

For this reason I would like to argue that one of the major challenges facing historians of contemporary East Central Europe in the era of Brexit is the need to rethink the construction of the post-socialist political order and pay closer attention to its evolving political languages. These languages use the same terms as liberal democracies elsewhere but often mean something quite different due to their particular evolution in this region. One of the most significant aspects here is the role of constitutionalism.

Constitutionalism and the rule of law was ascribed a crucial role in securing the transition to liberal democracy and market economy after the breakdown of communism. A vision of the rule of law, based on Euro-American constitutional developments along with human rights codifications, was widely understood as a central pillar of post-communist democratisation. It also appeared as a defence against both a possible Jacobin radicalisation of the 1989 democratic revolutions and the authoritarian tendencies of various charismatic transition politicians. Independent and robust juridical institutions with constitutional courts at the helm were established with the aim of immunising - through a strict separation of powers and judicial review - the new democracies against any abuse of power. But some scholars, such as the sociologists Paul Blokker and Marta Bucholc, have since pointed out that this 'received wisdom' of domestic liberal elites and their Western advisors was dangerously one-sided.

Belief in liberal constitutionalism in post-communist Europe was closely tied to a notion of internal and external sovereignty based on a robust national state. For countries which had just regained their independence from Moscow, national sovereignty was dear and should have been 
derived, above all, from constitutions and legal systems. This liberal bias, however, was castigated first from the democratic left. As we know already from Herman Heller, the German interwar lawyer and social democrat, and his polemic with the illiberal critic of liberal democracy, Carl Schmitt, it is a mistake to localise sovereignty solely in the nation state, since the sovereignty of the state cannot be separated from the sovereignty of the people. Both are mutually dependent. In the 1990s left-wing critics of liberal constitutionalism, such as the Czech left-liberal jurisprudence scholar, former 68er and dissident, František Šamalík, identified - presciently - an imbalance between the 'liberal moment' (which stressed negative freedoms substantiating economic interests and property redistribution) and the 'democratic moment' (which strove for broader participation and political equality). He warned that the tendency to severely reduce citizens' positive freedoms would ultimately undermine the legitimacy of the system by depriving it of its fundamental source, that is, the sovereignty of the people, giving rise to what Pierre Rosanvallon later called 'democratic distrust'.

A decade after 1989 the liberal constitutionalism, and what we often refer to more generally as the 'liberal consensus', of the early post-communist period, did indeed come under attack. Prospects for EU accession were high for many countries, the transformation dynamics were decelerating and conservative national forces were in the ascendance across the region. Criticism of the liberal consensus was expressed not so much in social, but rather in cultural and symbolic terms. This was largely because the biggest prize of the long-awaited 'return to Europe' (accession to the EU) had turned into a significant structural problem.

Post-communist countries applying to join the EU in the 1990s 'outsourced' much of the legislative work, which should have been the subject of political negotiation in domestic parliaments, to the EU accession process. The implementation of the 'Acquis Communautaire' (the accumulated body of EU law and obligations) was a largely bureaucratic and legislative process, rather than a democratic one. The integration process entailed too many institutional and technical transfers, and too little local democratic political deliberation. As the legal scholar Jiří Přibán argued, EU membership was considered such a political priority that the approximation to European law was not discussed and merely justified as a historical necessity. There was also a strong pedagogical element in the accession process for post-communist countries. The European Commission deployed the so-called Copenhagen criteria to judge when post-communist countries were 'mature' enough to join the club. This was different from earlier enlargements. For the United Kingdom in 1973, but also for later members such as Austria, Finland and Sweden, membership of the EU was seen as a partnership (that could also result in divorce). By contrast, the huge eastern enlargement of May 2004 was framed as a test that had to be passed, and left the aftertaste of an uneven relationship between master and pupil.

The neoliberal economic transformation, combined with the bureaucratised, legalistic and pedagogic EU accession process, disengaged many important social and economic conflicts from political struggles. This opened up a space for political mobilisation based on symbolic and identity issues. History and historical arguments played a crucial role in this mobilisation. Political discourse focused on anti-communism, fierce public debates about the recent past, the promotion of new forms of national patriotism and the creation of new institutes of national memory. Later on, in the Hungarian and the Polish cases, the anti-liberal campaign even took the form of counter-constitutional project. The powerful populist backlash in the region appears to undermine the liberal tenet about the neutrality of the rule of law. In a manner that is ironically similar to earlier Marxist criticisms, many populists disparage of the idea of a neutral and higher law that can provide a depoliticised framework for political struggle. Instead, they push for an approach based on the 'sovereignty of the people', where laws reflect the will of the national majority. They oppose a mystified neutrality that supposedly masks the will and interests of a domestic liberal minority elite or the Brussels diktat.

Unlike Václav Klaus's brand of critique of the EU, which was inspired by some elements of British conservatism, the new, much more powerful wave of Euroscepticism stirred by national 
populist parties such as Fidesz and PiS builds on defensive autochthonist cultural resentments, rather than any consistent ideological criticism of European federalism and supranationalism. All varieties of Euroscepticism, however, share one common element: an emphatic 'sovereignism' that is allegedly defending the interests of the nation and the people against supposedly elitist, bureaucratic and liberal-cosmopolitan-globalist projects, be they at home or in Europe. Undoubtedly, these ugly majoritarian democracies are stripping themselves of legal checks and balances, pushing through the interests of majorities at the expense of 'minorities' and drawing on xenophobic sentiments and Christian civilisational imagery. But the fact remains that the recent Eurosceptic and anti-liberal revolt leans on broad and deeply entrenched democratic distrust and anti-pedagogical revolt, all of which was planted and nurtured in the fertile fields of post-communist liberal transformation. For historians of contemporary East Central Europe, therefore, the Brexit era challenges us to rethink the nature of 1989 as a turning point in the history of the region. Eschewing simplistic explanations (for example about the impact of neoliberalism) in favour of more nuanced explorations of the character of cultural configurations and political languages of the post-socialist order, and their varied historical legacies, is crucial for writing future histories of democracy, sovereignty and Euroscepticism in East Central Europe and Europe as a whole after Brexit.

Cite this article: Kopeček, M. 2019. Sovereignty, 'Return to Europe' and Democratic Distrust in the East after 1989 in the Light of Brexit. Contemporary European History 28: 73-76, doi: 10.1017/S0960777318000851 